Katarzyna Kubiszewska*

\title{
PROBLEM EFEKTYWNOŚCI BANKÓW W LITERATURZE PRZEDMIOTU
}

\section{Wprowadzenie}

Efektywność banku jest jedną z podstawowych miar oceny jego działalności. Dlatego tak ważne jest analizowanie jej poziomu, jak również czynników oddziałujących na efektywność zarówno pozytywnie, jak i negatywnie.

Celem artykułu jest przeprowadzenie przeglądu literatury związanej z problemem. Opracowanie zostało podzielone na trzy części. Pierwszą poświęcono przedstawieniu różnych koncepcji pojęcia efektywności, ze szczególnym jego uwzględnieniem w odniesieniu do sektora bankowego. W drugiej części omówiono miary i techniki badania poziomu efektywności banków, zaś w trzeciej przedstawiono wyniki wybranych badań nad tym zagadnieniem. Ważnym zagadnieniem są badania w odniesieniu do sektorów bankowych w okresie transformacji. W artykule wykorzystano literaturę przedmiotu dostępną powszechnie, ze szczególnym uwzględnieniem zagranicznych źródeł.

\section{Pojęcie efektywności}

Literatura przedmiotu dotycząca problemu efektywności w gospodarce jest bardzo bogata. Od lat toczy się dyskusja nad definicją, znaczeniem, jak również czynnikami oddziałującymi na efektywność. Pojęcie efektywności może być utożsamiane z optymalną alokacją dóbr w społeczeństwie. Można tutaj wyodrębnić wiele koncepcji. Pierwszą z nich jest zdefiniowanie efektywności jako maksymalizacji dobrobytu, osiągniętej dzięki optymalnej satysfakcji. Po wtóre, w sensie Pareto, efektywność to stan, kiedy zmiana satysfakcji jednego podmiotu nie będzie negatywnie

* Politechnika Gdańska, Wydział Zarządzania i Ekonomii. 
oddziaływać na poziom satysfakcji innego posiadacza. Ponadto, efektywność jest osiągana wówczas, gdy krańcowe koszty wynikające z realizacji określonego celu są zrównane z krańcowymi korzyściami, związanymi z jego osiągnięciem.

Z punktu widzenia ekonomicznego efektywność można określić jako stosunek między uzyskiwanymi efektami a nakładami potrzebnymi do ich uzyskania. Im wyższa jest ta relacja, innymi słowy - im różnica między efektami a nakładami jest większa - tym efektywność danego obiektu jest uznana za wyższą. Bardziej precyzyjnie efektywność rozumie P. Rose ${ }^{1}$, dla którego istotą jest tempo wzrostu przychodów nad kosztami, a w konsekwencji rosnący dochód podmiotu. Można powiedzieć, że utożsamił on efektywność z zyskownością.

W inny sposób definiuje to pojęcie W.L. Jaworski². Według niego przez działanie efektywne rozumie się takie, które nie tylko prowadzi do osiągnięcia zamierzonych celów, ale zapewnia uzyskanie wymiernych korzyści ekonomicznych, większych od poniesionych nakładów. Oznacza to, że efektywność jest tym samym, co sprawność, która jest pochodną dwóch czynników, tj. skuteczności i ekonomiczności. Skutecznym jest natomiast takie działanie, w wyniku którego osiąga się rezultat - wynik równy założonemu. Natomiast ekonomicznym jest działanie, które pozwala osiągnąć założony rezultat przy najniższym koszcie.

Problemem efektywności banków zajął się też M. Capiga ${ }^{3}$, który dzieli efektywność na trzy typy. Pierwszym jest efektywność organizacyjna dotycząca celów organizacji, posiadanych przez nią zasobów, warunków istniejących wewnątrz i poza organizacją oraz czasu, w którym oceniane jest to pojęcie. Drugim zaś jest efektywność finansowa, odnosząca się do oceny wyników finansowych i sytuacji finansowej banku na podstawie sprawozdań finansowych, i jest ona oparta na wskaźnikach finansowych. Trzeci wyodrębniony typ stanowi efektywność kosztowa, która polega na ocenie, czy daną wielkość produkcji osiągnięto przy odpowiedniej wielkości i strukturze nakładów.

W literaturze przedmiotu można znaleźć także rozróżnienie efektywności na efektywność techniczną, kosztową oraz dochodową. M.J. Farrell ${ }^{4}$ zaprezentował termin efektywności technicznej. Według niego jest to relacja między produktywnością danego obiektu a granicą jego rzeczywistych możliwości produkcyjnych. Tak sformułowana efektywność może przyjmować wartości od 0 do $100 \%$. Tylko poziom

1 P. Rose, Zarzadzanie bankiem komercyjnym: Wytwarzanie i sprzedaż usług finansowych, Związek Banków Polskich, Warszawa 1997, s. 152-154, 418.

2 Bankowość. Podręcznik Akademicki, red. W.L. Jaworski, Z. Zawadzka, Poltext, Warszawa 2006, s. 604-611.

3 M. Capiga, Ocena działalności placówki operacyjnej banku: Dylematy metodologiczne i praktyczne, Wydawnictwo Akademii Ekonomicznej w Katowicach, Katowice 2003, s. 57-61.

4 M.J. Farrell, The Measurement of Effective Efficiency, "Journal of Royal Statistical Society" 1957, Seria A, No. 120(3). 
efektywności 100\% oznacza wytwarzanie produkcji przy wykorzystaniu optymalnej pod względem kosztów kombinacji nakładów ${ }^{5}$. Poziom niższy niż 100\% oznacza stopień nieefektywnego wykorzystania zasobów, a więc odstępstwo od efektywnego planu produkcji oraz to, że otrzymana produkcja mogłaby być wytwarzana mniejszym nakładem. Występująca wówczas nieefektywność techniczna rośnie proporcjonalnie do rozmiaru dystansu od optymalnej efektywności.

Na podstawie przeprowadzonej analizy, inny podział efektywności banków wprowadza G. Rogowski', wyodrębniając dwa kierunki badań. Obok analizy efektywności technicznej proponuje on analizę efektów skali oraz zakresu produkcji. Rogowski precyzuje podstawowe miary efektywności technicznej: efektywność techniczna ukierunkowana na nakłady i efektywność techniczna ukierunkowana na efekty. Ta pierwsza, inaczej zwana efektywnością typu X, określa maksymalny poziom proporcjonalnej redukcji nakładów niezbędnych dla wytworzenia danych efektów. Jej celem jest przeprowadzenie analizy kosztów, co jest jednoznaczne z oceną poziomu efektywności zarządzania kosztami przez instytucję. Efektywność techniczna ukierunkowana na efekty jest narzędziem analizy przychodów. Przeprowadzone dotychczas badania efektywności banków w głównej mierze koncentrowały się na efektach skali oraz zakresie produkcji. Zdecydowanie mniej uwagi poświęcano efektywności technicznej, która ma znacznie większy wpływ na kształtowanie się efektywności banku. Na podstawie wyników badań stwierdzono, iż nieefektywność techniczna wpływa w $20 \%$ na wzrost kosztów, podczas gdy brak efektów skali lub zakresu produkcji jedynie w 5\%. Oznacza to, że poprawa efektywności technicznej może umożliwić średnią redukcję kosztów o 20\%, podczas gdy korzyści wynikające z osiągnięcia wielkości zapewniającej występowanie efektów skali mogą umożliwić średnią redukcję kosztów o 5\%?.

Bardzo ważne jest określenie, jakie czynniki miały decydujący wpływ na kształtowanie efektywności. Efektywne działanie systemu bankowego zależy od kilku istotnych elementów. Dzieje się tak wówczas, kiedy sektor bankowy jest poddany silnym bodźcom do dokładnego monitorowania dłużników, bezpiecznego i zyskownego inwestowania oraz zdywersyfikowania portfela depozytów w ten sposób, aby minimalizować ryzyko utraty płynności. Innym czynnikiem pozytywnie oddziałującym na efektywność jest potwierdzanie statusu banków jako instytucji zaufania

5 M. Pawłowska, Konkurencja i efektywność na polskim rynku bankowym na tle zmian strukturalnych i technologicznych, „Materiały i Studia NBP” 2005, nr 192, s. 20-24.

6 G. Rogowski, Metody analizy i oceny banku na potrzeby zarzadzania strategicznego, Wydawnictwo Wyższej Szkoły Bankowej, Poznań 1998, s. 61-67.

7 T. Siudek, Efektywność w teorii i praktyce na przykładzie wybranych banków spółdzielczych $w$ Polsce, „Zeszyty Naukowe SGGW - Ekonomika i Organizacja Gospodarki Żywnościowej” 2008, nr 65, s. 5. 
publicznego. Oznacza to nieprzerwane dążenie do przekonania społeczeństwa, że rynek i poszczególne instytucje działają zgodnie z odpowiednimi przepisami i standardami, a interes klientów jest stawiany na pierwszym miejscu. Ponadto, istotnym czynnikiem wpływającym na efektywność jest konkurencja międzybankowa. Rozwój konkurencji zależy od struktury danego rynku oraz zachowań jego uczestników, zarówno po stronie popytu, jak i podaży. W literaturze przedmiotu panuje uzasadniony pogląd, że sektor bankowy jest sektorem o pewnej specyfice, która wynika z konieczności zapewnienia bezpieczeństwa i stabilności całego systemu, także w drodze ciągłego zwiększania efektywności swojego działania. Efektywne działanie systemu bankowego oznacza, że funkcjonuje on jednocześnie poprawnie w zakresie systemu regulacji, jak i konkurencji, co skutkuje wyższym poziomem bezpieczeństwa dla konsumenta i przyczynia się do poprawy wizerunku banku jako instytucji zaufania publicznego.

$\mathrm{Z}$ drugiej strony, na zmniejszenie efektywności istotny wpływ ma ryzyko związane $\mathrm{z}$ zarządzaniem powierzonymi przez klientów środkami pieniężnymi. Innym czynnikiem są metody wyboru projektów inwestycyjnych. Stosowanie preferencyjnych warunków prowadzi do zachwiania funkcjonowania mechanizmu efektywnej alokacji zasobów, a w konsekwencji negatywnie wpływa na całą gospodarkę. Struktura własnościowa także istotnie oddziałuje na efektywność systemu bankowego. Znaczenie ma tutaj udział banków kontrolowanych przez skarb państwa, jak również wpływ inwestorów zagranicznych na lokalny rynek bankowy.

\section{Miary efektywności banków}

Efektywność banków mierzona jest przy wykorzystaniu narzędzi o charakterze zarówno jakościowym, jak i ilościowym. Jedną z najprostszych technik pomiaru efektywności jest analiza wskaźnikowa, opierająca się na danych ze sprawozdań finansowych. Pomimo że miary te są często krytykowane z powodu ich niskiej wartości informacyjnej oraz braku powiązań z teorią mikroekonomii, są one najczęściej wykorzystywane, głównie ze względu na ich prostotę oraz klarowność ${ }^{8}$. Jednym z przykładów jest marża odsetkowa, która wyjaśniana jest jako relacja wyniku z odsetek do średnich aktywów pomniejszonych o odsetki zapadłe od należności zagrożonych. Wskaźnik ten mówi również o efektywności dochodowej banków. Wynagrodzenie pobierane przez banki za realizację usług bankowych z jednej strony stanowi element

8 Ibidem. 
ich przychodów, a z drugiej może być rozpatrywane jako koszt społeczny korzystania z sektora bankowego. Dotychczas realizowane badania ${ }^{9}$ wskazują na silny negatywny związek między wysoką wartością marży a stopniem wzrostu gospodarczego. Wzrost wskaźnika oznacza spadek efektywności sektora, czemu towarzyszy niższy wzrost gospodarczy. Kolejną miarą efektywności sektora bankowego jest relacja kosztów operacyjnych do wyniku działalności bankowej, skorygowanego o wynik pozostałych przychodów i kosztów operacyjnych, co świadczy przede wszystkim o efektywności kosztowej. Innymi miarami efektywności sektora bankowego są analiza wielkości i struktury przychodów lub/i kosztów, jak również wielkość wskaźników ROE i ROA, jako elementów wskaźnikowej analizy finansowej.

Bardziej skomplikowane techniki pomiaru efektywności przedsiębiorstw, w tym banków, wyrosły na gruncie mikroekonomicznej teorii producenta oraz ekonometrii i badań operacyjnych ${ }^{10}$. Metody parametryczne polegają na ustaleniu za pomocą klasycznych narzędzi estymacji ekonometrycznej parametrów funkcji produkcji, określających zależność pomiędzy nakładami i wynikami banku. Jednym z przykładów parametrycznych metod oceny efektywności jest Stochastic Frontier Analysis (SFA), opracowana w 1977 r. przez D.J. Aigner ${ }^{11}$, a zaadaptowana do oceny instytucji bankowych przez G.D. Forrier i C.A.K. Lovell ${ }^{12}$. Metoda opiera się na analizie funkcji produkcji lub funkcji kosztów, przedstawiających korelację miedzy wynikami a nakładami w instytucji. Porównuje ona, jak się mają koszty działania badanej instytucji do optymalnego poziomu kosztów w innym, zbliżonym wielkością przedsiębiorstwie.

Inną grupę metod stanową metody nieparametryczne, które opierają się na programowaniu matematycznym. Najpopularniejszą nieparametryczną metodą wykorzystywaną w celu pomiaru efektywności jest Data Envelopment Analysis (DEA), w literaturze przedmiotu uważana za najlepsze narzędzie badań nad efektywnością techniczną. Została opracowana w 1978 r. przez A. Charnesa ${ }^{13}$, który przedstawił tę miarę efektywności jako iloraz pojedynczego wyniku i pojedynczego nakładu. Przedmiotem analizy efektywności w tym wypadku jest to, jak dana jednostka decyzyjna przekształca posiadane nakłady $\mathrm{w}$ wyniki. $\mathrm{Z}$ upływem czasu wprowadzono

9 A. Demirgüç-Kunt, L. Laeven, R. Levine, Regulations, Market Structure, Institutions, And the Cost of Financial Intermediation, "Journal Of Money, Credit and Banking" 2004, Vol. 36, No. 3.

${ }^{10}$ K. Jackowicz, W. Kuryłek, Rentowność banków komercyjnych działających w Polsce w latach 1995-2001 a bieżące decyzje menedżerskie i skumulowane w czasie skutki tych decyzji, „Bank i Kredyt” 2004, nr 2, s. 39.

11 D.J. Aigner, C.A.K. Lovell, P. Schmidt, Formulation and Estimation of Stochastic Frontier Production Functions, "Journal of Econometrics" 1977, No. 6, s. 21-37.

12 G.D. Forrier, C.A.K. Lovell, Measuring The Cost Efficiency In Banking Econometric And Linear Programming Evidence, "Journal of Econometrics" 1990, No. 46, s. 229-245.

13 A. Charnes, W.W. Cooper, A. Rhoes, Measuring The Efficiency Of Decision Making Units, "European Journal of Operational Research" 1978, No. 2(6), s. 429-444. 
do modelu DEA dodatkowe rozwiązania, np. o stałych (CRS DEA lub DEA CCR ${ }^{14}$ ), zmiennych (VRS DEA) lub nierosnących (NIRS DEA lub DEA BCC ${ }^{15}$ ) efektach skali.

\section{Efektywność banków w badaniach}

Od wczesnych lat 90. XX w., dzięki postępom w przepływie informacji, prędkości komunikacji i rozwoju technologii, banki mogą wykonywać wiele swoich tradycyjnych usług dużo bardziej efektywnie. W związku z tym, wskaźnik kosztów do dochodów spada niemal wszędzie w różnym stopniu ${ }^{16}$, co oznacza, że banki ponoszą niższe koszty w zakresie poszczególnych oferowanych usług i produktów. Dotychczasowe badania wskazują na pozytywny i bardzo istotny wpływ tego wskaźnika na efektywność banków i w konsekwencji - ich rentowność ${ }^{17}$. Relacja ta oznaczalaby, że efektywność operacyjna jest warunkiem poprawy opłacalności systemu bankowego. Z drugiej strony, A.N. Berger i D.B. Humphrey ${ }^{18}$ podkreślają, iż krańcowa zdolność kontroli kosztów (tzw. X-efektywność) jest o wiele ważniejsza niż przeciętne korzyści skali i zakresu. Przy tej samej skali i asortymencie produktów banki mogą ponosić koszty o ok. $20 \%$ wyższe niż minimum dla sektora z powodu złego zarządzania. Również Berger ${ }^{19}$ stwierdza, że X-efektywność lub lepsze zarządzanie zasobami, są konsekwentnie związane z wyższymi zyskami.

Sektor bankowy w krajach członkowskich Unii Europejskiej jest przedmiotem badań w zakresie efektywności i jej determinant od dawna ${ }^{20}$. Autorzy badań potwierdzili

14 Nazwa pochodzi od pierwszych liter nazwisk autorów tej metody: Charnes, Cooper, Rhodes.

${ }^{15}$ Nazwa pochodzi od pierwszych liter nazwisk autorów tej metody: Banker, Charnes, Cooper.

16 U. Albertazzi, L. Gambacorta, Bank Profitability and the Business Cycle, "Journal of Financial Stability" 2009, No. 5, s. 393-409.

${ }_{17}$ C. Alexiou, V. Sofoklis, Determinants of Bank Profitability, Evidence from the Greek Banking Sector, "Economic Annals" 2009, s. 182, 93-118; Athanasoglou, P. Panayiotis, N. Sophocles Brissimis, D. Matthaios Delis, Bank - Specific, "Industry-Specific and Macroeconomic" 2005; A. Dietrich, G. Wanzenried, Determinants of Bank Profitability Before and During the Crisis: Evidence from Switzerland, "Journal of International Financial Markets, Institutions And Money” 2011; A. García-Herrero, S. Gavilá, D. Santabárbara, What Explains the Low Profitability of Chinese Banks?, "Journal of Banking and Finance" 2009, No. 33, s. 20802092; Pasiouras, F., Kosmidou, K., Factors Influencing The Profitability of Domestic And Foreign Commercial Banks in The European Union, "Research in International Business and Finance" 2007, No. 21, s. 222-237.

18 A.N. Berger, D. B. Humphrey, Efficiency of Financial Institutions, International Survey And Directions For Future Research, "European Journal of Operational Research" 1997, No. 98(2), s. 175-212.

19 A.N. Berger, R. Deyoung, G.F. Udell, Efficiency Barriers To The Consolidation of The European Financial Services Industry, "European Financial Management" 2000, No. 6.

${ }^{20}$ J.W.B. Bos, H. Schiedel, Comparing Efficiency in European Banking, A Meta Frontier Approach, "Research Series Supervision" 2003, No. 57, De Nederlandche Bank, Amsterdam; D. Hollo, M. Nagy, Bank Efficiency in The Enlarged European Union, "Working Paper" 2006, No. 3, MNB, Budapest; B. Casu, 
zróżnicowany poziom efektywności działania europejskich sektorów bankowych. J.W.B. Bos i H. Schiede ${ }^{21}$ porównywali poziom efektywności sektora bankowego w Belgii, Niemczech i Francji, dochodząc do wniosku, że najwyższy poziom występuje w bankach belgijskich. D. Hollo i M. Nagy ${ }^{22}$ natomiast przeprowadzili analizę efektywności dochodowej wszystkich krajów członkowskich UE, w rezultacie czego dowiedli, że nie ma zbyt istotnej różnicy (luka efektywności 0,04\%) w poziomie efektywności pomiędzy krajami UE (15) i UE (10). Zaś B. Casu i C. Girardone ${ }^{23}$ wykazali brak oddziaływania wzajemnego między konkurencją a efektywnością sektora bankowego.

Przeprowadzono badania wykorzystujące różne techniki w celu porównania efektywności pomiędzy bankami zagranicznymi i krajowymi. I. Hasan i A. Lozano-Vivas ${ }^{24}$ przeprowadzili badania dla rynku bankowego w Hiszpanii, które dowiodły, że banki zagraniczne charakteryzują się zbliżonym poziomem efektywności dochodowej jak banki krajowe. A.N. Berger i współpracownicy ${ }^{25}$ porównali efektywność banków we Francji, Niemczech, Hiszpanii, Wielkiej Brytanii i USA. W wypadku sektora bankowego w USA ustalono, że banki krajowe są średnio mniej efektywne pod względem kosztów niż banki zagraniczne. Odmienne wyniki uzyskano dla rynku bankowego w Unii Europejskiej. Stwierdzono, że wyższą efektywnością kosztową i dochodową charakteryzują się banki krajowe w porównaniu z bankami zagranicznymi w trzech państwach (Francja, Niemcy, Wielka Brytania), ale różnica nie była uznana za statystycznie znaczącą. K. Kosmidou ${ }^{26}$ wykazał, że banki krajowe osiągają wyższą ogólną efektywność w porównaniu do banków zagranicznych w Wielkiej Brytanii. I. Hasan i W.C. Hunter ${ }^{27}$, A. Mahajan ${ }^{28}$ oraz C.E. Chang ${ }^{29}$ stwierdzili, że zagraniczne banki w USA są mniej efektywne kosztowo niż banki krajowe. Podobne wyniki uzyskano

C. Girardone, A Comparative Study of The Cost Efficiency of Italian Banking Conglomerates, "Managerial Finance", 2002, nr 28(9), s. 3-23.

${ }^{21}$ J.W.B. Bos, H. Schiedel, op.cit.

${ }^{22}$ D. Hollo, M. Nagy, op.cit.

${ }^{23}$ B. Casu, C. Girardone, op.cit.

${ }^{24}$ I. Hasan, A. Lozano-Vivas, Foreign Banks, Production Technology and Efficiency: Spanish Experience, WP Presented at The Georgia Productivity Workshop III, Athens, Georgia, 1998.

25 A.N. Berger, R. Deyoung, G.F. Udell, op.cit.

${ }^{26}$ K. Kosmidou, F. Pasiouras, J. Floropoulos, Linking Profits To Asset-Liability Management of Domestic and Foreign Banks in The UK, "Applied Financial Economics" 2004, Vol. 14, No. 18, s. 1319-1324.

27 I. Hasan, W.C. Hunter, Efficiency of Japanese Multinational Banks in USA, "Research in Finance" 1996, No. 14 , s. $157-173$.

28 A. Mahajan, N. Rangan, A. Zardkoohi, Cost Structures in Multinational And Domestic Banking, "Journal of Banking And Finance" 1996, No. 20(2), s. 238-306.

29 C.E. Chang, I. Hasan, W.C. Hunter, Efficiency of Multinational Banks: An Empirical Investigations, "Applied Financial Economics" 1998, No. 8(6), s. 1-8. 
w badaniach dotyczących rynku australijskiego. Korzystając z metody DEA, M. Sathye ustalił, że zagraniczne banki są mniej efektywne niż krajowe ${ }^{30}$.

Zrealizowane zostały także liczne badania efektywności i stabilności systemów bankowych w różnych krajach, w różnych okresach, np. M. Bordo, A. Redish i H. Rockoff $^{31}$, porównując wyniki amerykańskiego systemu bankowego do kanadyjskiego w latach 1920-1980, zaobserwowali dużo większą stabilność, mierzoną odsetkiem zlikwidowanych banków, w systemie kanadyjskim w porównaniu do sytuacji w amerykańskim. Spekulowali, iż przyczyna takiego stanu rzeczy leży w oligopolistycznej strukturze rynku bankowego w Kanadzie, chociaż analiza poziomu nominalnych i realnych stóp procentowych, zarówno depozytowych, jak i kredytowych, nie daje szczególnych dowodów na wystąpienie renty monopolowej w badanym okresie. Z kolei analiza bilansu sektora bankowego wskazuje, że banki w Kanadzie były dużo bardziej rentowne w porównaniu do banków działających w USA. Wskazuje to na fakt, że w Kanadzie sektor bankowy był bardziej stabilny i efektywny, lecz nie mniej konkurencyjny niż w USA. F. Carpie ${ }^{32}$ badał stabilność i efektywność brytyjskiego systemu bankowego w latach 1890-1940. Nie zanotowując w podanym okresie ani paniki bankowej, ani kryzysu finansowego, doszedł do wniosku, iż sektor bankowy w Wielkiej Brytanii był bardzo stabilny, co także obrazuje słaby wpływ wielkiego kryzysu lat 30. na Wielką Brytanię. W odniesieniu do struktury rynkowej pojawiła się tam tendencja do konsolidacji banków, która doprowadziła do uformowania się na rynku struktury oligopolistycznej. Jednak, pomimo szerokiego wachlarza usług oferowanych przez banki, Carpie nie odnalazł dowodów na zadziwiająco wysokie zyski, co doprowadziło go do wniosku, że banki te były równocześnie dość nieefektywne. Badanie te potwierdzają hipotezę, iż mniej konkurencyjny system bankowy może również być stabilny.

W odniesieniu do bliższych nam lat, G. Hoggarth, A. Milne oraz G. Wood ${ }^{33}$ porównali brytyjski system bankowy do niemieckiego w okresie ostatniej dekady. Okazało się, że zyski banków w Wielkiej Brytanii były wyraźnie wyższe niż w Niemczech, ale także dużo bardziej zmienne. Wyższa zyskowność banków w Wielkiej Brytanii może być wytłumaczona tym, że brytyjskie banki osiągnęły wyższe zyski pochodzące z innych źródeł niż odsetki bankowe, a także niższymi kosztami pracowników,

\footnotetext{
${ }^{30}$ M. Sathye, X-Efficiency In Australian Banking: An Empirical Investigation, "Journal of Banking And Finance" 2001, No. 25, s. 613-630.

${ }^{31}$ M. Bordo, A. Redish, H. Rockoff, A Comparison of The US And Canadian Banking Systems In The 20 th Century: Stability And Efficiency, 1995 za E. Carletti, Ph. Hartmann, Competition And Stability: What's Special About Banking?, "ECB Working Papers" 2002, No. 26, European Central Bank.

${ }^{32}$ F. Capie, Prudent And Stable (But Inefficient), 1995 za E. Carletti, Ph. Hartmann, op.cit.

${ }^{33}$ G. Hoggarth, A. Milne, G. Wood, Alternative Routes to Banking Stability: A Comparison Of UK and German Banking Systems, "Financial Stability Review" 1998, Bank Of England.
} 
zaś w Niemczech wykazano większą i bardziej stabilną inflację oraz istniała mniejsza konkurencja ze strony banków zagranicznych. Doświadczenia tych dwóch systemów bankowych mogą wskazywać na dwa odmienne przypadki: niemiecki system bankowy jest mniej konkurencyjny, ale bardziej stabilny, zaś w Wielkiej Brytanii sektor bankowy jest bardziej konkurencyjny, ale kosztem jego stabilności. Także w latach 80. C. Staikouras oraz G. Wood ${ }^{34}$ przeprowadzili w podobny sposób badania w dwóch innych krajach: Hiszpanii i Grecji. Odkryli, że system hiszpański jako całość jest zarówno bardziej efektywny pod względem zyskowności, jak i bardziej stabilny w porównaniu do sektora bankowego w Grecji. Wyjątkiem jest grupa banków komercyjnych w Hiszpanii, która była znacząco mniej stabilna. To prowadzi do konkluzji, iż sektor w Hiszpanii jest bardziej konkurencyjny niż grecki, w którym bardzo wysoki udział ma skarb państwa i publiczne środki finansowe. Jest też bardziej stabilny.

Światowa literatura dotycząca badań efektywności banków jest bardzo obszerna i bogata. Prowadzone obserwacje można podzielić na te, które skupiają się na podejściu mikroekonomicznym oraz prowadzone z makroekonomicznego punktu widzenia. $Z$ perspektywy mikro, kwestia efektywności sektora bankowego ma kluczowe znaczenie, zwłaszcza dla gospodarki Europy Środkowo-Wschodniej, biorąc pod uwagę proces transformacji gospodarki jako całości, w tym wzmocnienie konkurencji ze względu na istotny udział banków zagranicznych w regionie - zarówno jako inwestycje typu greenfield i przejęcia, ale także wskutek poprawy ram instytucjonalnych, prawnych i nadzorczych. Z makro perspektywy, efektywność sektora bankowego wpływa na koszty pośrednictwa finansowego i ogólną stabilność systemów finansowych, jako że banki stanowią ich rdzeń w tym regionie ${ }^{35}$. Rzeczywiście, poprawa wyników bankowości wskazuje na lepszą alokację zasobów finansowych, a tym samym przysługuje się wzrostowi inwestycji, które sprzyjają wzrostowi gospodarczemu ${ }^{36}$.

Realizowane są także badania biorące pod uwagę relacje między własnością i efektywnością w krajach transformacji. D. Grigorian i V. Manole ${ }^{37}$ przy wykorzystaniu metody DEA ocenili efektywność sektorów bankowych w 17 krajach w latach 1995-1998. Autorzy wyodrębnili silną pozytywną korelację między własnością zagraniczną a większą efektywnością i nieco słabszą pomiędzy jakością ostrożnościowego systemu regulowania sektora bankowego a efektywnością jego działania.

${ }^{34}$ C. Staikouras, G. Wood, Banking Competition And Stability In Europe, "Journal of International Banking Regulation" 1999, No. 1.3 za E. Carletti, Ph. Hartmann, op.cit.

35 European Commission, The Western Balkans In Transition, "Enlargement Papers" 2004, No. 23, Directorate General for Economic and Financial Affairs.

${ }^{36}$ I. Weill, Is There A Gap in Bank Efficiency Between CEE and Western European Countries? (Central and Eastern Europe), "Comperative Economic Studies" 2007, No. 49.

37 D. Grigorian, V. Manole, Determinants Of Commercial Bank Performance In Transition, "World Bank Policy Research Paper" 2002, No. 2850. 
Tabela 1. Wybrane badania efektywności sektorów bankowych w krajach przechodzących transformację gospodarczą

\begin{tabular}{|c|c|c|c|c|c|c|c|c|c|}
\hline \multirow{2}{*}{ Autor } & \multirow{2}{*}{ Metoda } & \multirow{2}{*}{ Kraj } & \multirow{2}{*}{$\begin{array}{c}\text { Okres } \\
\text { badawczy }\end{array}$} & \multicolumn{2}{|c|}{ Efektywność kosztowa } & \multicolumn{2}{|c|}{ Efektywność dochodowa } & \multicolumn{2}{|c|}{ Efektywność } \\
\hline & & & & wyższa & niższa & wyższa & niższa & wyższa & niższa \\
\hline Kraft, Tirtiroglu & SFA & Chorwacja & 1994-1995 & SB & & & & & \\
\hline Kraft et al. & SFA & Chorwacja & 1994-2000 & BZ & & & & & \\
\hline Nikiel, Opiela & DFA & Polska & $1997-2000$ & BZ & & & BZ & & \\
\hline Jemric, Vujcic & DEA & Chorwacja & $1995-2000$ & $\mathrm{BZ}, \mathrm{BN}$ & & & & & \\
\hline Grigorian, Manole & DEA & 17 krajów transformacji & 1995-1998 & $\mathrm{BZ}$ & & & & & \\
\hline Isik, Hassan & DEA & Turcja & 1988-1996 & BP & & & & & $\mathrm{BP}$ \\
\hline Hasan, Marton & SFA & Węgry & 1993-1998 & $\mathrm{BZ}$ & & BZ & & & \\
\hline Weill & SFA & Polska i Czechy & 1997 & $\mathrm{BZ}$ & & & & & \\
\hline Fries, Taci & SFA & 12 EŚW & 1994-2001 & $\mathrm{BZ}, \mathrm{BP}$ & & & & & \\
\hline Rossi et al. & SFA & 9 EŚW & 1995-2002 & & banki & & banki & banki & \\
\hline Bonin et al. & SFA & 11 krajów transformacji & $1996-2000$ & BZ & & BZ & $\mathrm{BP}$ & & $\mathrm{BP}$ \\
\hline Carvallo, Kasman & SFA & 16 krajów z Ameryki Łacińskiej & 1995-1999 & DB & & & & & \\
\hline Kasman & SFA & Polska i Czechy & $1995-2000$ & BZ & & & & & \\
\hline Kasman, Yildirim & SFA & 8 EŚW & 1995-2002 & & & BZ & & & \\
\hline Havrylchyk & DEA & Polska & $1997-2001$ & & & & & BZ & \\
\hline Yidrimim, Philippatos & SFA/DFA & 12 krajów transformacji & $1993-2000$ & $\mathrm{BZ}$ & & & BZ & & \\
\hline
\end{tabular}

Uwaga: BZ - banki zagraniczne, BN - banki narodowe, BP - banki prywatne, DB - duże banki.

Źródło: Opracowanie własne. 
Wzięli pod uwagę instytucje z co najmniej 30-procentowym udziałem inwestorów zagranicznych w akcjonariacie. H. Yildirim i G. Philippatos ${ }^{38}$ zaś oszacowali efektywność sektorów bankowych za pomocą metody SFA w 12 krajach w okresie transformacji od 1993 do $2000 \mathrm{r}$. Autorzy uważają, że banki z większościowym udziałem zagranicznych inwestorów są bardziej zyskowne, ale mniej wydajne niż inne banki w tych krajach. Kwesta różnic pomiędzy poziomem zysków i efektywnością kosztową była przedmiotem badania S. Fries i A. Taci ${ }^{39}$, którzy dowiedli, że niższymi kosztami funkcjonowania sektorów bankowych charakteryzowały się te kraje, w których udział zagranicznych inwestorów w całkowitych aktywach sektora jest znaczący. Prowadzone badania potwierdzają, że banki zagraniczne charakteryzują się wyższym poziomem efektywności kosztowej w krajach transformujących się. Tabela 1 przedstawia realizowane badania w zakresie efektywności kosztowej w krajach transformujących gospodarkę.

\section{Podsumowanie}

Efektywność banków jest jednym z ważniejszych zakresów badań. Wyniki analiz przeprowadzanych różnymi metodami i technikami nie są jednoznaczne. Jednak wskazują one na istnienie pewnych determinant, oddziałujących na zwiększenie lub zmniejszenie poziomu efektywności. Istotnym tematem badań w literaturze przedmiotu są także sektory bankowe krajów przechodzących transformację systemową. Ważnym czynnikiem oddziałującym na sytuację banków w tych krajach jest zaangażowanie kapitału zagranicznego, czego dowodzą analizy wielu autorów.

\section{Bibliografia}

Aigner D.J., Lovell C.A.K., Schmidt P., Formulation and Estimation of Stochastic Frontier Production Functions, "Journal of Econometrics" 1977, No. 6.

Albertazzi U., Gambacorta L., Bank Profitability and the Business Cycle, "Journal of Financial Stability" 2009, No. 5.

\footnotetext{
${ }^{38}$ H. Ylldırım, G. Philippatos, Efficiency In Banks: Recent Evidence from The Transition Economies of Europe, 1993-2000, "The European Journal of Finance" 2007, No. 13, s. 123-143.

39 S. Fries, A. Taci, Banking Reform And Development in Transition Economies, "Working Papers EBRD" 2002, No. 71.
} 
Alexiou C., Sofoklis V., Determinants of Bank Profitability, Evidence from the Greek Banking Sector, "Economic Annals" 2009.

Athanasoglou Panayiotis P., Brissimis S.N., Delis M.D., Bank - Specific, "Industry-Specific And Macroeconomic" 2005.

Bankowość. Podręcznik Akademicki, red. W.L. Jaworski, Z. Zawadzka, Poltext, Warszawa 2006.

Berger A.N., Deyoung R., Udell G.F., Efficiency Barriers to The Consolidation of The European Financial Services Industry, "European Financial Management" 2000, No. 6.

Berger A.N., Humphrey D.B., Efficiency of Financial Institutions, International Survey And Directions For Future Research, "European Journal of Operational Research" 1997, No. 98(2).

Bonin J., Hassan I., Wachtel P., Bank Performance, Efficiency and Ownership in Transition Countries, "Journal of Banking And Finance" 2005, No. 29.

Bordo M., Redish A., Rockoff H., A Comparison of The US and Canadian Banking Systems in The 20 ${ }^{\text {th }}$ Century: Stability and Efficiency, $1995 \mathrm{za}$ E. Carletti, Ph. Hartmann, Competition And Stability: What's Special About Banking?, "ECB Working Papers” 2002, No. 26, European Central Bank.

Bos J.W.B., Schiedel H., Comparing Efficiency in European Banking, A Meta Frontier Approach, "Research Series Supervision" 2003, No. 57, De Nederlandche Bank, Amsterdam.

Capie F., Prudent And Stable (But Inefficient), 1995 za E. Carletti, Ph. Hartmann, Cometition And Stability: What's Special About Banking?, "Working Papers" 2002, No. 26, European Central Bank.

Capiga M., Ocena działalności placówki operacyjnej banku: Dylematy metodologiczne i praktyczne, Wydawnictwo Akademii Ekonomicznej w Katowicach, Katowice 2003.

Carvallo O., Kasman A., Cost Efficiency in The Latin American and Caribbean Banking Systems, "Journal of International Financial Markets, Institutions and Money" 2005, No. 15.

Casu B., Girardone C., A Comparative Study of The Cost Efficiency of Italian Banking Conglomerates, "Managerial Finance" 2002, No. 28(9).

Casu B., Molyneux P., A Comparative Study of Efficiency in European Banking, "Applied Economics" 2003, No. 35.

Chang C.E., Hasan I., Hunter W.C., Efficiency of Multinational Banks: An Empirical Investigations, "Applied Financial Economics" 1998, No. 8(6).

Charnes A., Cooper W.W., Rhoes A., Measuring The Efficiency of Decision Making Units, "European Journal of Operational Research" 1978, No. 2(6).

Demirgüç-Kunt A., Laeven L., Levine R., Regulations, Market Structure, Institutions, And The Cost of Financial Intermediation, "Journal of Money, Credit And Banking" 2004, Vol. 36, No. 3.

Determinants of Bank Profitability, MPRA Paper 153, University Library of Münich, Germany, Revised 2006. 
Dietrich A., Wanzenried G., Determinants of Bank Profitability Before and During The Crisis: Evidence From Switzerland, "Journal of International Financial Markets, Institutions And Money" 2011.

European Commission, The Western Balkans In Transition, "Enlargement Papers" 2004, No. 23, Directorate General for Economic and Financial Affairs.

Farrell M.J., The Meaurement Of Effective Efficiency, "Journal of Royal Statistical Society" 1957, Serie A, No. 120(3).

Forrier G.D., Lovell C.A.K., Measuring The Cost Efficiency in Banking Econometric And Linear Programming Evidence, "Journal of Econometrics" 1990, No. 46.

Fries S., Taci A, Banking Reform And Development in Transition Economies, "Working Papers EBRD" 2002, No. 71.

García-Herrero A., Gavilá S., Santabárbara D., What Explains The Low Profitability of Chinese Banks?, "Journal of Banking and Finance" 2009, No. 33.

Grigorian D., Manole V., Determinants of Commercial Bank Performance in Transition, "World Bank Policy Research Paper" 2002, No. 2850.

Hasan I., Hunter W.C., Efficiency of Japanese Multinational Banks in USA, "Research in Finance" 1996, No. 14.

Hasan I., Lozano-Vivas A., Foreign Banks, Production Technology And Efficiency: Spanish Experience, "Working Paper Presented at The Georgia Productivity Workshop III" 1998, Athens, Georgia.

Havrylchyk O., Efficiency in The Polish Banking Industry: Foreign Versus Domestic Banks, "Journal of Banking and Finance" 2006, No. 30.

Hoggarth G., Milne A., Wood G., Alternative Routes To Banking Stability: A Comparison of UK and German Banking Systems, "Financial Stability Review" 1998, Bank of England.

Hollo D., Nagy M., Bank Efficiency In The Enlarged European Union, "Working Paper" 2006, No. 3, MNB, Budapest.

Isik I., Hassan M.K., Technical, Scale and Allocative Efficiencies of Turkish Banking Industry, "Journal of Banking and Finance" 2002, No. 26.

Jackowicz K., Kuryłek W., Rentowność banków komercyjnych działających w Polsce w latach 1995-2001 a bieżace decyzje menedżerskie i skumulowane w czasie skutki tych decyzji, „Bank i Kredyt” 2004, nr 2, 2004.

Jemric I., Vujcic B., Efficiency of Banks in Croatia: A DEA Approach, "Working Paper" 2002, No. 7, Croatian National Bank.

Kasman A., Efficiency And Scale Economies in Transition Economies: Evidence From Poland And The Czech Republic, "Emerging Markets Finance and Trade" 2005, No. 41.

Kasman A., Yildirim C., Cost and Profit Efficiencies in Transition Banking: The Case of New EU Members, "Applied Economies" 2006, No. 38. 
Kosmidou K., Pasiouras F., Floropoulos J., Linking Profits To Asset-Liability Management of Domestic and Foreign Banks in The UK, "Applied Financial Economics" 2004, Vol. 14, No. 18.

Kraft E., Hofler R., Payne J., Privatization, Foreign Bank Entry and Bank Efficiency in Croatia: A Fourier-Flexible Function Stochastic Cost Efficiency Analysis, "Working Paper" 2002, No. 9, Croatian National Bank.

Kraft E., Tirtiroglu D., Bank Efficiency in Croatia: A Stochastic Frontier Approach, "Journal of Comparative Economics" 1998, No. 26.

Mahajan A., Rangan N., Zardkoohi A., Cost Structures in Multinational and Domestic Banking, "Journal of Banking and Finance" 1996, No. 20(2).

Nikiel E., Opiela T., Customer Type and Bank Efficiency in Poland: Implications for Emerging Market Banking, "Contemporary Economic Policy" 2002, No. 20.

Pasiouras F., Kosmidou K., Factors Influencing The Profitability of Domestic and Foreign Commercial Banks in The European Union, "Research in International Business and Finance" 2007, No. 21.

Pawłowska M., Konkurencja i efektywność na polskim rynku bankowym na tle zmian strukturalnych i technologicznych, „Materiały i Studia NBP” 2005, nr 192.

Rogowski G., Metodologia analiz efektywności i efektu skali banków, „Bank i Kredyt” 1998, No. 11.

Rogowski G., Metody analizy i oceny banku na potrzeby zarządzania strategicznego, Wydawnictwo Wyższej Szkoły Bankowej, Poznań 1998.

Rose P., Zarzadzanie bankiem komercyjnym: Wytwarzanie i sprzedaż ustug finansowych, Związek Banków Polskich, Warszawa 1997.

Rossi S., Schwaiger M., Winkler G., Managerial Behavior and Cost/Profit Efficiency in The Banking Sectors of Central and Eastern European Countries, "Working Papers" 2005, No. 96, Oesterreichische Nationalbank.

Sathye M., X-Efficiency in Australian Banking: An Empirical Investigation, "Journal of Banking and Finance" 2001, No. 25.

Staikouras C., Wood G., Banking Competition And Stability In Europe, "Journal of International Banking Regulation" 1999, No. 1.3 za E. Carletti, Ph. Hartmann Competition and Stability: What's Special About Banking?, "Working Papers" 2002, No. 26, European Central Bank.

Stępień K., Konsolidacja a efektywność banków w Polsce, Cedewu, Warszawa 2004.

Weill L., Is There A Gap in Bank Efficiency Between CEE and Western European Countries? (Central and Eastern Europe), "Comperative Economic Studies" 2007, No. 49.

Yildırım H., Philippatos G., Efficiency in Banks: Recent Evidence from The Transition Economies of Europe, 1993-2000, “The European Journal Of Finance” 2007, No. 13. 


\section{On the Question of Bank Effectiveness}

The purpose of this article is to analyze the literature related to the problem of bank effectiveness. The article is divided into three parts. The first one is devoted to the various concepts of effectiveness. The second part discusses the methods and tools used to measure the level of efficiency of a banking market. The third part presents results of selected studies on this issue, with a special emphasis on the banking sectors of economies during systematic transformation.

Keywords: efficiency, banking sector, efficiency during transformation

\section{La question de l'efficacité de la banque}

Le but de cet article est d'analyser la littérature liée au problème de l'efficacité de la banque. L'article est divisé en trois parties. La première partie est consacrée aux différents concepts de l'efficacité. La deuxième partie traite des méthodes et des outils utilisés pour mesurer le niveau de l'efficacité d'un marché bancaire. La troisième partie présente les résultats des études sélectionnées sur cette question, avec un accent particulier sur les secteurs bancaires des économies lors de la transformation systématique.

Mots-clés: l'efficacité, le secteur bancaire, l'efficacité lors de la transformation

\section{Вопрос эффективности банков в литературе}

Эффективность банка является одним из ключевых показателей при оценке его деятельности. Таким образом, важен анализ его уровня и факторов, положительно или отрицательно воздействующих на него. Цель статьи заключается в обзоре литературы по этой теме. Статья разделена на три части. В первой из них представлены различные концепции, относящееся к понятию эффективности. Во второй рассматриваются методы измерения уровня эффективности банковского рынка, а третья представляет результаты избранных исследований с упором на банковский сектор в переходный период.

Ключевые слова: эффективность, банковский сектор, эффективность в переходный период 
